\title{
About the Romanian opera for children and the choral moments
}

\author{
Consuela RADU-ȚAGA ${ }^{1}$
}

\begin{abstract}
The stories of the little ones were the starting point of some operas' creation. In the Romanian musical context the first operas for children appear in the first half of the 20th century. The composers opt for the connection with the folkloric treasure, connection made both at the level of literary language, and the musical one. The horizons, the accomplishments, and the conceptual maturations are the three creative stages in the evolution of this musical subgenre. The colorful world of the children calls for choral moments that fill the stage with characters, the choral landscape bringing in timbral diversity. As well as the solo part, the choral moments are meant for adult voices (mixed choir, men choir, and female choir) or for children choir (choir on equal voices, with 2, 3, or 4 voices). The simple forms of the folkloric music are present, couplet-refrain alternation led to a certain tendency to miniature. The popular melos is widely used, rhythmical figures are complex, and the effects of the orchestral timbre stimulate the optimistic character, the sweet lyricism, exuberance and cheerfulness.
\end{abstract}

Key-words: Romanian opera for children, choir, folklore, get-at-able melody, entertaining rhythm

\section{Introduction}

The approach to the universe of childhood was most often mediated by the fairy tale world. Specific modalities for transfiguration and ennobling of reality, the stories of the little ones were the starting point of some operas' creation. The fantastic circumstances, the characters endowed with supernatural powers, the success of Good over Evil made up facts that animated the fairy tale world. We find the etymology of the Romanian word in the term of Slavic origin basnŭ, which means figment, mere concept.

\footnotetext{
${ }^{1}$ Lecturer PhD George Enescu National University of Arts, Iași, taga_consuela@yahoo.com
} 


\section{Horizons}

The play Înşir'te mărgăritar [Queue up perly] by Victor Eftimiu was musically translated by Hermann Klee, setting up in 1924 the opera Făt-Frumos [Prince Charming], on a libretto signed by Ioan Dan. Dealing with the struggle between Good and Evil, his opera opposes two characters: Făt-Frumos and Zmeul Zmeilor [The King of the Dragons]. Get-at-able melody is distinguished, being necessary for the possibilities for receiving of children, and the musical expression is played with orchestral device of neoromantic type.

Followed the year 1935 with the opera Papură Impărat [Hurry Emperor], composed by Lucian Teodossiu, on his own libretto, after the fairy-scene of Vasile Alecsandri. The adventures of the main heroes, Păcală [Tweedle Dum] and Tândală [Tweedle Dee] were followed throughout 4 acts (5 tableaus), the musical-dramatic unfolding requiring the presence of the choir.

The chorus from the third act is distinguished, causing popular sonorities. "The clearness and the sobriety of the structure, the pregnant melodiousness and the plasticity of the musical representations are the merits of this opera" (Cosma, 1962, p. 89).

The well-known fairy tale of Ion Creangă, Capra cu trei iezi [The Goat with Tree Kids] got musical array thanks to Alexandru Zirra. Composed in 1938, the opera for little ones and the big ones take place in 3 acts. At the feast in the forest, with all kind of creatures, the popular song Cine te-a-ndoit cu vinul [Who doubted you with wine] is sung:

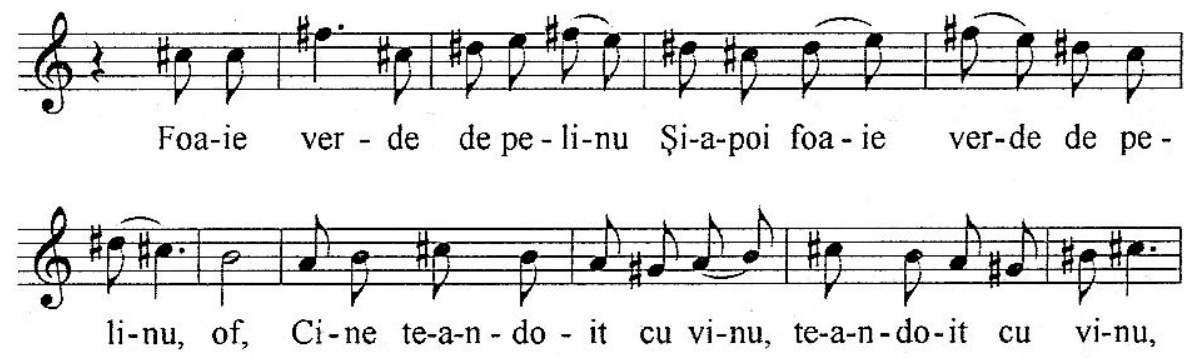

Fig. 1. Al. Zirra - "Capra cu trei iezi", act III

Considering him a Humperdinck of the Romanians, George Enescu appreciated Zirra's creation, stating that "Capra cu trei iezi is very well written, humorous, and has always the necessary dramatic contrast... He liked the ending a lot because competed with the enescian rhapsody" (Vasile 2005, 180). 


\section{Achievements}

Attracted by Povestea țapului [The Goat's story] of Serghei Marșak, the composer Max Eisikovits wrote in 1953 an opera on a subject arranged by lon Bartalis (Hungarian version) and Ilie Balea. The fairy tale proposes the conflict between the world of Good, represented by the positiv character - the Goat - and the world of Evil, with the Dragon and his devilish creatures. After 3 acts (5 tableaus) the forces of Good triumph, because the cleverness and the courage can overcome the darkness and the slavery. The opera begins with the picture of a quiet home, located at the edge of the village, the unique joy of the elders without children being a droll goat. The second tableau changes the frame with a sunny meadow; in an atmosphere of song and dancing (6/8 con moto) a group of girls picks flowers and mushrooms. The melody of modal origin is treated poliphonically, being necessary the participation of 4 female voices.

In the second act the choir wears clothes of Leprechauns. From the onomatopoeic utterances like hipi, hipi (men choir) and niha, niha (mixed choir), the second act ends with a choral structure that impersonates the joy of Evil forces' victory, because at the moment, the Goat falls into captivity and he is sent to forced labor. The folklore from Transilvania is exploited in a particular harmonic language, with an intense chromatization and a refined treatment of dissonances. The expressive value of the instrumental timbres stand out in a transparent orchestration, "which does not avoid, but assimilates certain verismo influences and conquests of Wagner's music" (Cosma 1964, 214). The final victory and the joy of seeing the beloved elders again is rendered by the popular character of the peasant chorus in allegretto grazioso. The entire village sings and dances, and the the purity of the feelings is described by a melodious and accessible music:

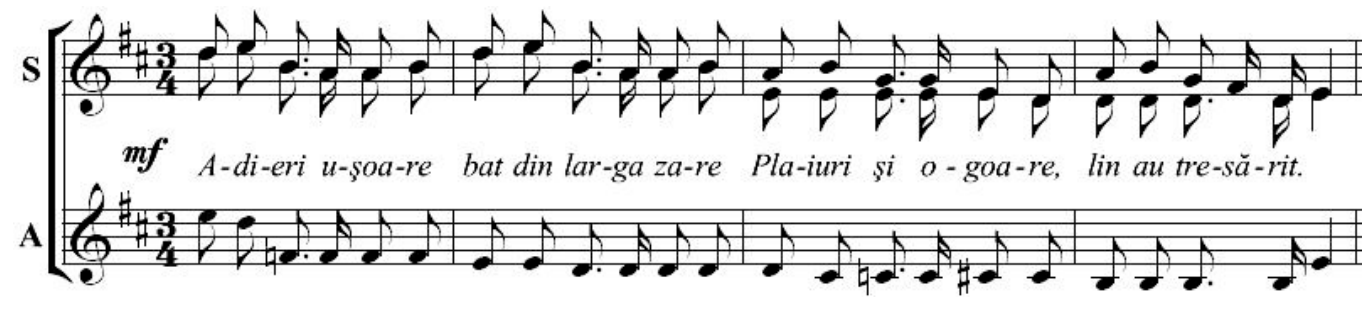

Fig. 2. M. Eisikovits - "Povestea ţapului" (Goat's story), act III

In the second opera dedicated to the children theatre, Eisikovits addresses a popular fable. The 2 acts ( 3 tableaus) from Fântâna cu bucluc [The Nutty Fountain] were completed in 1960, on a libretto signed by Lili Marton. The themes dealt does 
not depart from the one proposed by Povestea țapului; the main character, the Smart Bunny, establishes the justice of the simple and good ones, and the power of the Good triumphs over the tyrannical forces.

From the popular lamentation's modulations of the chorus accompanying the cheerful song of the wanderer Bunny, the end of the first act develops with personal polyphonic mark. The second act, the moment when the tyrants are double-crossed by the Bunny, is also completed by a choral intervention. The drunken tyrants argue with the echo of the nutty fountain and they are fighting hard for the acquisition of the crown.

Like Bartók, Cornel Trăilescu chose to compose an opera on a topic of Perrault's fairy tale (Puss in Boots). The opera was finished in 1961, on a libretto version arranged by Tudor Mușatescu and Nina Stoiceva. The opera for children Motanul încălțat has 3 acts, the choir appearing in the second act. "The scene represents a hall from the Emperor's castle, after binge. The Emperor and the courtiers, drunken, are sleeping in different positions. Snoring is heard" (Trăilescu $1972,46)$. A soloist (basso profondo) is detaching from the eight courtiers (basses) which are singing in unison. A descending chromatic scale is used to achieve the effect of yawning, with determined intonation to the group:

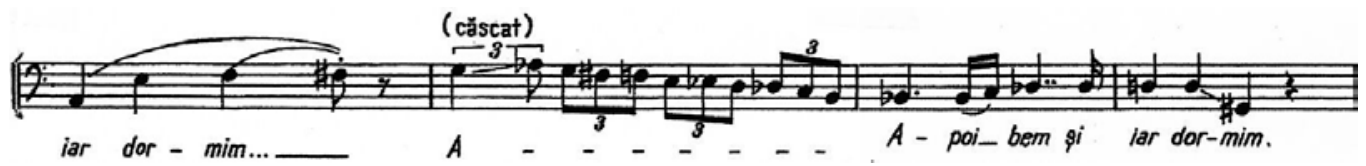

Fig. 3. C. Trăilescu - "Motanul încălţat" (Puss in Boots), act II, tableau I

and sliding to sprechgesang at the soloist:

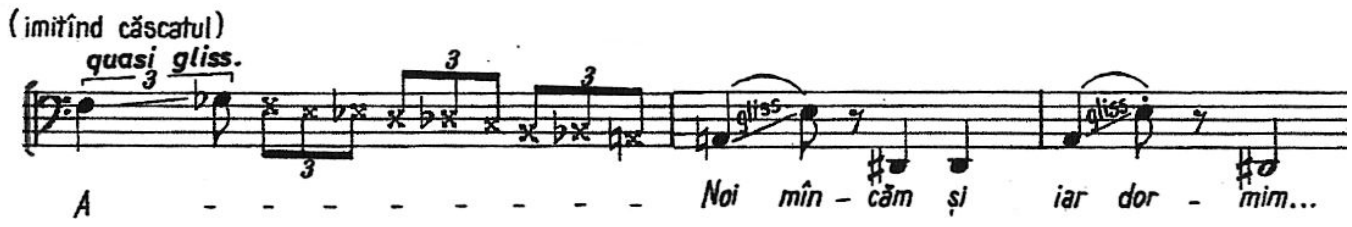

Fig. 4. C. Trăilescu - "Motanul încălţat", act II, tableau I

The men group remains on stage to attend the dialogue between the Emperor and the Pussycat. The figure of His Greatness is praised in Maestoso, because the Day of Emperors will be celebrated in a short time. The choral group supports and amplifies the sonority through the homophonic texture and deepens the dramatic character. 
The soft timbre of female voices appears in the third tableau that take place in the Young Lady's closet. The nanny (role for mezzo-soprano) and the little maids sing a Lullaby in tranquillo. The female voices sing with the closed mouth, humming the solo part of the nanny. The low dynamics are folded to the character, and the choral group intensifies the dynamics of the moment.

The male group reappears; the female voices and male voices come together under the name of courtiers. A vigorous assembly results, with a dynamics in fortissimo that uses the stress accents. The structure of the mixed choir is preserved in the first tableau of the second act, the physical presence more than the musical one being necessary. The choral replies are very few and limited; the courtiers' point out some aspects related to the actions of the main characters: Ionică and his Pussycat.

The end brings good mood, the encouragement to drink and to sing according to the event we are attending. The trumpeters announce the arrival of many guests at the wedding between Ionică and the Young Lady, on which occassion the composer introduces a lot of characters extracted from other stories: The Snow White, followed by her seven Dwarfs, The Little Red Riding Hood, Zmeul Zmeilor, Muma pădurii [The Mother of the Forest], Tweedle Dum, White Moor, The Goat with three kids, and so on...This delicious appearances are to the taste of the public!

\section{Conceptual maturations}

One of the most representative national composers, placed on the top of musical avant-garde from Romania, Ștefan Niculescu covered a lot of musical genres. He reached the field of musical theatre with the opéra-ballet for children The Book with Apollodorus (1975), on Gellu Naum's libretto. The 75 minutes of the unusual show bring on stage 5 main characters, among which the tenor penguin, llie kangaroo, Amedeu lion and mixed choir. The musical color is the fundamental item of the composer's mindset, which takes up the idea of timbre interval from a previous creation entitled Scene [Scenes].

The Contemporary Era has continued the realm of metaphors, of hyperbolas, of imagination that shakes hand with the fabulous, raising the issue of conceiving music for children. The consecrated pages of Hans Christian Andersen's narratives receveid 2 musical figments through Liana Alexandra: the opera extravaganza Crăiasa zăpezii [The Snow Queen] composed in 1979, and the ballet Mica sirenă [The Little Mermaid] made up in 1982. The first opera of Liana Alexandra, understood a sung by the children, has a single act, and uses a scenario written by 
the composer. The adventures of the brave Gretchen searching for Karl reach up to the Kingdom of the eternal snow. The idea of the sacrifice is inserted through the attempt to save the beloved one, through the heroine's effort to surpass her. The narrative has 2 outlines: one is for Karl, the other one is for Gretchen, and at the end the two dimensions come together under the dome of love's victory with the value of knowledge.

The sustained evolution of the opera connects the thinking in sequence of the sections, resulting 12 musical numbers. Next to the two soloists (soprano and alto or countertenor), the children choir participates like a true storyteller and commentator. The beginning and the end are marked by the choir in a columnar pattern. The flute foreshadows the reccurence of the choir, in Waltz rhythm, and the large diminuendo opens the perspective on the serious meanings detached from the stories pages. From time to time the choir restores the atmosphere of fantasy, of peace, and of confidence in the triumph of the Good. For example the structure of the number 4 brings the choir into the dialogue with the pipe organ, and the next pages of heterophony, in the hypostasis of the number eight's texture declare delayed melodic fragments. The modal world is present both in the melodic part and in the harmonic one; the preference for the interval of forth and fifth is a peculiar feature. The poetic atmosphere is rendered by a small group of instrumentalists; beside the pipe organ and celesta, moments of interest return to the percussion instruments (glockenspiel, vibraphone, xylophone, gong, triangle, bells), to the compartment of the blowing instruments individualized according to the requirements of the fairy tale's epic unfolding (flute, trumpet, trombone), to which is added the strings.

The compositional approach of Liana Alexandra stands out by clearity, coherence, melodic inspiration, harmonical luxuriance. The economy of the vocabulary issues is imposed by the gender approach, focusing on consonance ${ }^{2}$. "The composer aspires to accessibility in perception by showing simplicity of the musical discourse (with repetitive-pulsatory predilection)" (Anghel 1997, 46).

After almost two decades since Corneliu Cezar composed his first opera, he is again attracted by the miracle of the lyrical stage. Exponent of the avant-garde composition and promoter of the sonic spectralism, Corneliu Cezar writes in 1983 the music and the libretto of the opera Pinocchio, after the Collodi's story. The creation outlines through melodic mindset by certain style, the accessibility of the language, the predominance of the linear issue, the naturalness of the scenes' unfolding full of dynamism and coloring. At the end of the opera the children choir sings in unison:

2 Liana Alexandra and his husband Șerban Nichifor were the promoters of the neoconsonant direction. 


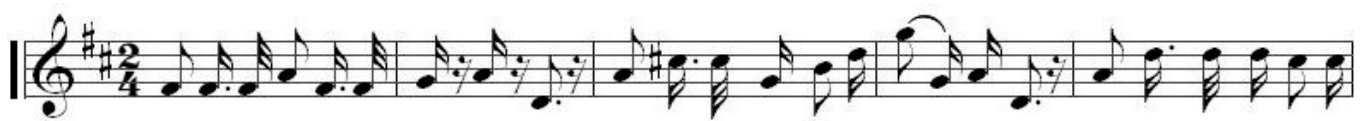

Ci ne-o săfa-că a - şa ca el o s-o pă-teas-că a-ha!_ la fel! Noi cre-dem în-să că

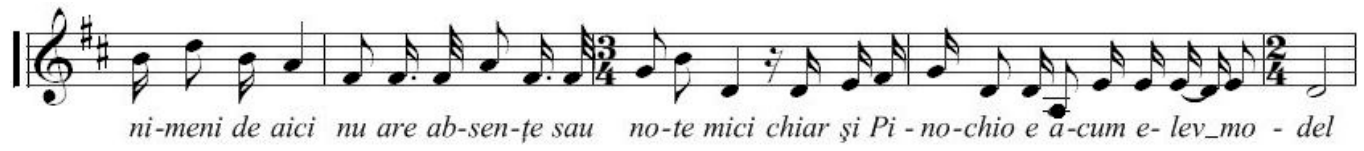

Fig. 6. C. Cezar - "Pinocchio", 2nd part

The same year 1983 enriched the lyrical repertoire with the opera for children entitled Child's Heart, signed by Carmen Petra-Basacopol, inspired by Edmondo de Amicis's novel. Audible name of the Romanian contemporary music, the composer encompassed diverse genres, insisting on the timbral particularities of the chamber music and exploring the technical-expressive issues of the preferred instrument the harp. Hence"the association with the Impressionism is inevitable, but the substance of the harmony based on the Romanian modes customize the difining style of Carmen Petra-Basacopol" (Sandu-Dediu 2002, 157).

Child's Heart ${ }^{3}$ is an opera set up on 2 acts, 5 tableaus, with prologue and epilogue. The multitude of the characters appeals, on the one hand, to the presence of the adult voices (a soprano, a tenor, a mezzo-soprano and a bass that easily pass from one role to another), and on the other hand to the children voices, which performe solo roles (Marco, his brother, the little girl), but they are also integrated on groups that dynamically color the entire development. So, the children choir depicts the multitude of the port sellers, the people from the ship, the little horses, or the voice of the forest.

The whole action runs around Marco, a boy from Genoa, at the age of 12, who wanders the world to find his mother gone to work in Argentina. Marco crosses the Atlantic Ocean, travels by the boat, the train and the carriage, he meets people of all kinds, he experiences moments of fear and excitement, but he overcomes all the obstacles and he manages to save his mother from death. When losefa sees her own child again, she decides to undergo surgery. The surgery succeeds, so Marco and losefa peacefully come back home.

The children choir evolves in unison, at 2 or 3 voices; it accompanies the epic evolution, painting the dramaturgical context. It encourages the hero in his actions;

\footnotetext{
${ }^{3}$ The Opera Class from George Enescu National University of Arts from lași participated of the first and unique edition of Opera Fringe Festival held in Bucharest in 2016, where it won the third prize with the show Child's Heart by Carmen Petra-Basacopol; stage director Octavian Jighirgiu, conductor Consuela Radu-Țaga.
} 
it caresses the musical expression with a modal resounding universe, by a minimalist essence which results from the rich children's folklore. Musical scales with fewer sounds (pre-pentatonic), playings of thirds and fourths, to which is added step by step evolution, evolving towards the conquest of new pitches, by the transposition of the initial figures. In the rhythmical structure, not very complicated, outlines the presence of the claps, which hepls to maintain the pulse, and in the same time creates a picturesque setting. The choral score includes isorhythmical moments, but also the episodes of free imitation. I detained the refrain repeted from several times, which gave the tittle of the opera:

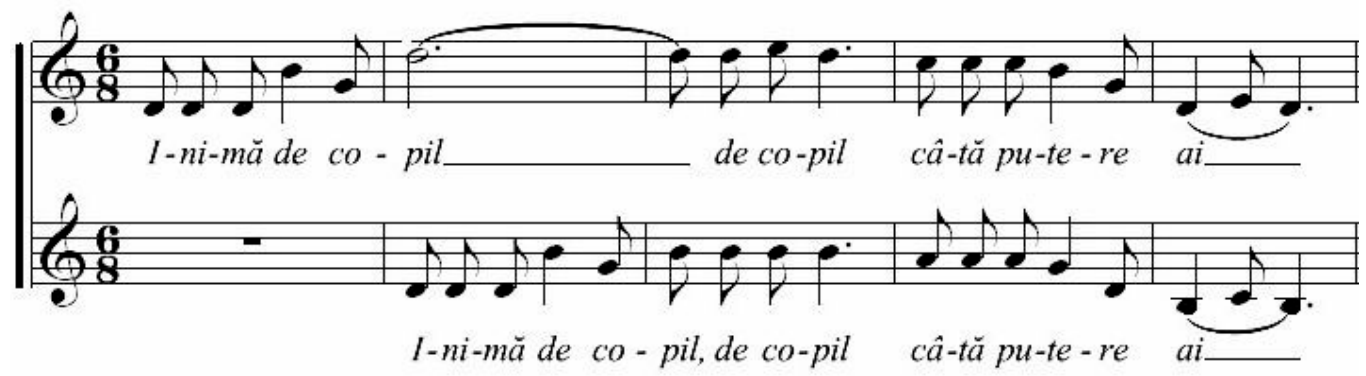

Fig. 7. C. Petra-Basacopol - "Child's Heart", act II, epilogue

The orchestral craft does not appeal to big touches, but it prefers solo interventions of instruments. The pure sonorities of the celesta and the harp are capitalized, and also the piano is present in the devise of the orchestra, the digital organ, the tubular bells, and because the most part of the action took part in Argentina, the tambourine and the maracas adhere to the musical rhetoric ${ }^{4}$. The concise language is anchored in a powerful Romantic vein, the final conclusion being born from a particular sensitivity: "the entire world is a ship on which we all ride on, parents and children" (Petra-Basacopol 1983, 80).

The big love of the composer Laurențiu Profeta was the musical theatre. The three acts of the musical Povestea micului Pan [The Little Pan's Story], on the libretto written by Eugen Rotaru, after Mattew James Barrie, are full of supple and beautiful songs, the solo episodes alternating with the choral ones. The enchanting universe proposes different roles performed by the big ones and the little ones; regarding to the choir, this is destinated only to the chidren's voices.

\footnotetext{
4 The presence of the tambourine and the maracas can also be viewed from the perspective of the African influences on creation of Carmen Petra-Basacopol, who lived a short amount of time in Marocco.
} 


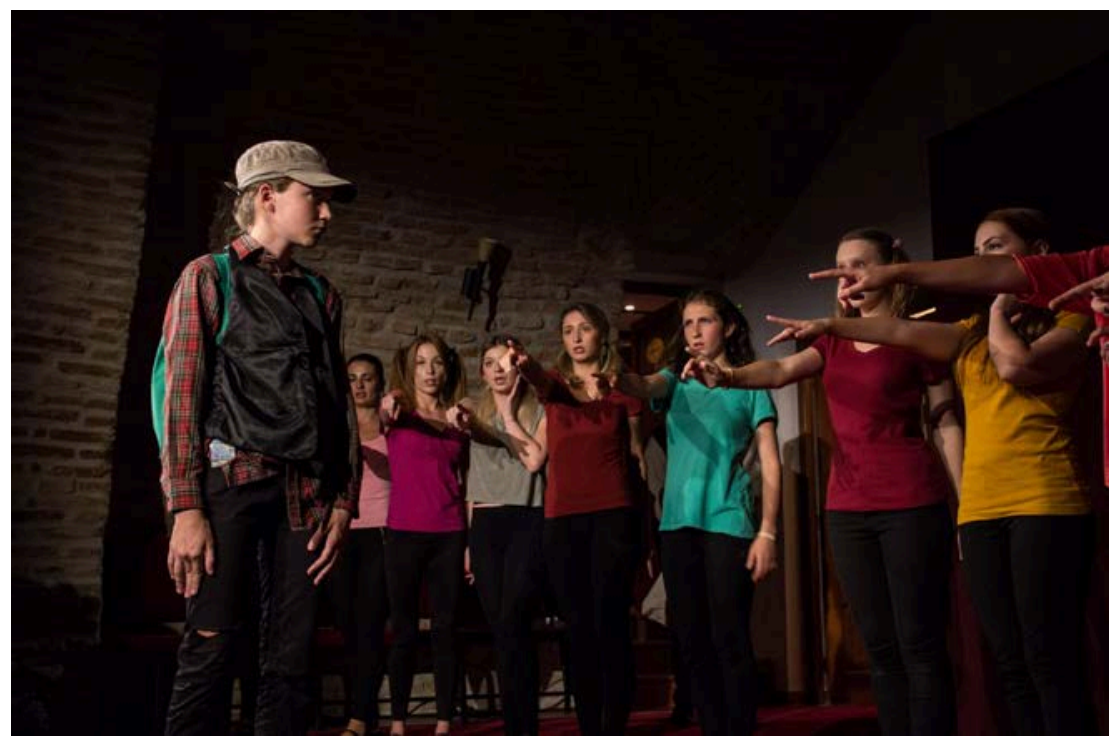

Fig. 8. Photo from the "Opera Fringe" Festival, House of Arts, Bucharest, September 2016

Profeta discovers the vein of the Romanian pop music, Povestea micului Pan representing a model for the later rock opera. The bunch of kids accompanies almost all the musical numbers; from the singing in unison, the choral structure opens at 2 or 3 voices, with soft intonations on vocalises (in the prologue, or the Lullaby of Mrs. Darling), or vigorous articulations. The amusement and the good cheer rule de whole atmosphere, the scherzando disposition being a good companion of the choral moments.

\section{Conclusions}

After vaudeville, operetta, comic opera, historical opera and popular drama, the opera for children comes to complete the scenery of the Romanian musical composition, with opuses that capitalized the literary and musical folklore, the modal system (by popular origin, and later by own creation), the children's folklore, the get-at-able melody, the aksak pattern and the entertaining rhythms, the sonorous effects made through the dynamic and agogic contrasts, the using of happy refrains, interjections, and onomatopoeias. The colorful world of the children calls for choral moments that fill the stage with characters, the choral landscape bringing in timbral diversity. If solo roles require performings made on 
the one hand by adult voices, on the other hand by chidren's voices, the choral moments are intended for the most part of the children's voices, from the singing in unison to the disposal at 3 or 4 voices. An artistic institution specialized in the repertoire of the little ones (opera, ballet, musical, operetta, lesson-concerts, theatre) exists in Romania, and this institution is called Opera comică pentru copii [Comic Opera for Children] from Bucharest.

\section{References}

Alexandra, Liana. 1979. Crăiasa zăpezii [The Snow Queen], general score, manuscript. Bucharest: UCMR Library.

Anghel, Irinel. 1997. Orientări, direcții, curente ale muzicii românești din a doua jumătate a secolului XX. [Guidelines, Directions, Movements in the Romanian Music from the second half of the 20th century]. Bucharest: Musical Publishing House

Cezar, Corneliu. 1983. Pinocchio, general score, manuscript. Bucharest: UCMR Library.

Cosma, Octavian Lazăr. 1962. Opera românească. Privire istorică asupra creației lirico-Dramatice [Romanian Opera. Historical view on lyrical-dramatic creation], vol. II. Bucharest: Musical Publishing House.

Eisikovits, Max. 1953. Povestea țapului [The Story of the Goat], general score, manuscript. Bucharest: UCMR Library.

Niculescu, Ștefan. 1975. Cartea cu Apolodor [The Book with Apollodorus], general score, manuscript. Bucharest: UCMR Library.

Petra-Basacopol, Carmen. 1983. Inimă de copil [Child's Heart], general score, manuscript. Bucharest: Musical Publishing House.

Profeta, Laurențiu. 1989. Povestea Micului Pan [The Little Pan's Story], canto-piano score. Bucharest: Musical Publishing House.

Sandu-Dediu, Valentina. 2002. Muzica românească între 1944-2000 [The Romanian Music between 1944-2000]. Bucharest: Musical Publishing House.

Trăilescu, Cornel. 1972. Motanul încălțat [Puss in Boots], canto-piano score. Bucharest: Musical Publishing House.

Vasile, Vasile. 2005. Alexandru Zirra. Bucharest: Musical Publishing House. 